\section{Cureus}

\title{
Deep Brain Stimulation for Obesity
}

\author{
Allen L. Ho ${ }^{1}$, Eric S. Sussman ${ }^{1}$, Michael Zhang ${ }^{1}$, Arjun V. Pendharkar ${ }^{1}$, Dan E. Azagury ${ }^{2}$, \\ Cara Bohon $^{3}$, Casey H. Halpern ${ }^{1}$
}

1. Department of Neurosurgery, Stanford University School of Medicine 2. Department of Surgery, Stanford University School of Medicine 3. Department of Psychiatry and Behavioral Sciences, Stanford University School of Medicine

$\square$ Corresponding author: Allen L.Ho, allenlho@gmail.com

Disclosures can be found in Additional Information at the end of the article

\section{Abstract}

Obesity is now the third leading cause of preventable death in the US, accounting for 216,000 deaths annually and nearly 100 billion dollars in health care costs. Despite advancements in bariatric surgery, substantial weight regain and recurrence of the associated metabolic syndrome still occurs in almost $20-35 \%$ of patients over the long-term, necessitating the development of novel therapies. Our continually expanding knowledge of the neuroanatomic and neuropsychiatric underpinnings of obesity has led to increased interest in neuromodulation as a new treatment for obesity refractory to current medical, behavioral, and surgical therapies. Recent clinical trials of deep brain stimulation (DBS) in chronic cluster headache, Alzheimer's disease, and depression and obsessive-compulsive disorder have demonstrated the safety and efficacy of targeting the hypothalamus and reward circuitry of the brain with electrical stimulation, and thus provide the basis for a neuromodulatory approach to treatment-refractory obesity. In this study, we review the literature implicating these targets for DBS in the neural circuitry of obesity. We will also briefly review ethical considerations for such an intervention, and discuss genetic secondary-obesity syndromes that may also benefit from DBS. In short, we hope to provide the scientific foundation to justify trials of DBS for the treatment of obesity targeting these specific regions of the brain.

Categories: Endocrinology/Diabetes/Metabolism, Psychiatry, Neurosurgery

Keywords: deep brain stimulation, obesity, hypothalamus, lateral hypothalamus, nucleus accumbens, metabolism, reward pathway, neuromodulation, food, behavior

\section{Introduction And Background}

Obesity is one of the most pressing public health issues in the United States. Obesity increases the risk of cardiovascular disease, diabetes, and cancer and is associated with a diminished

Received 01/12/2015 Review began 01/13/2015 Review ended 03/24/2015 Published 03/25/2015

\section{(C) Copyright 2015}

Ho et al. This is an open access article distributed under the terms of the Creative Commons Attribution License CC-BY 3.0., which permits unrestricted use, distribution, and reproduction in any medium, provided the original author and source are credited. quality of life and up to a 20-year decrease in life expectancy [1-4]. Currently, more than twothirds of adult Americans are overweight and over one-third are obese [5-6]. Obesity is now the third leading cause of preventable death in the US, accounting for 216,000 deaths annually and nearly 100 billion dollars in health care costs [7-8]. Unfortunately, conservative measures are associated with high rates of relapse, and thus surgical treatment options have gained favor [911]. Advancements in bariatric surgery have allowed for significant weight loss in $>90 \%$ of patients [12]. Interestingly, in addition to the anatomic sequelae of obesity surgery, which impose mechanical limitations on the magnitude of food consumption, neuroendocrinological effects appear to play a significant role in the efficacy of such procedures. Several studies have demonstrated postoperative changes in levels of circulating gut peptides that project to the brain [13], thereby underscoring the critical importance of central nervous system's feeding and satiety centers in the pathogenesis of obesity. Unfortunately, however, substantial weight 
regain and recurrence of the associated metabolic syndrome still occurs in almost $40 \%$ of patients over the long-term, necessitating the development of novel therapies [14-15].

Our continually expanding knowledge of the neuroanatomic and neuropsychiatric underpinnings of obesity has led to increased interest in neuromodulation, similar to other treatment-refractory disorders, such as obsessive-compulsive disorder. Deep brain stimulation (DBS) provides reversible electrical stimulation of neural circuitry and has been utilized as an effective and safe therapy for a wide variety of neurologic disorders [16-18]. While the precise mechanism of DBS remains unclear, it is well-established that high-frequency electrical stimulation clinically mimics the effects of neural ablative procedures [19-20]. However, the ability to titrate and/or reverse the effects of DBS make it the preferred method of neuromodulation [21-24]. Recent clinical trials of DBS in chronic cluster headache, Alzheimer's disease, and depression and obsessive-compulsive disorder have demonstrated the safety and efficacy of targeting the hypothalamus and reward circuitry of the brain with electrical stimulation, and thus provide the basis for a neuromodulatory approach to treatment-refractory obesity [16, 25-27].

While the role of the hypothalamus in the neurophysiology of obesity has been well-established for decades [28-29], more recent investigation has verified the importance of the brain's reward circuitry in the pathologic food-seeking behaviors typically seen in obesity [30-32]. This finding makes the nucleus accumbens (NAc) another favorable target for neuromodulation. In this study, we review the literature implicating these targets for DBS in the neural circuitry of obesity. We will also briefly review ethical considerations for such an intervention and discuss genetic secondary-obesity syndromes that may also benefit from DBS. In short, we hope to provide the scientific foundation to justify trials of DBS for the treatment of obesity targeting these specific regions of the brain.

\section{Review}

\section{Lateral hypothalamus as a target for DBS}

The hypothalamus is divided into multiple distinct functional regions; the main subregion that has received the most focus as a target for DBS is the lateral hypothalamus (LH). The LH has classically been recognized as the feeding center, providing anabolic control over the body's metabolism (Figure 1) [25]. The LH contains neurons that produce two orexinergic neuropeptides known as orexin and melanin-concentrating hormone (MHC). Intracerebroventricular infusion of either peptide elicits feeding [33]. Orexin-containing neurons project to various brain areas regulating feeding behavior. Over-expression of $\mathrm{MCH}$ in experimental models of obesity has been associated with insulin resistance and obesity, whereas MCH-knockout mice tend to be hypophagic and lean [34]. A variety of other peptides in addition to orexins have been implicated in LH activity, such as neuropeptide $\mathrm{Y}^{68}$, and agouti-related protein [35-39]. Moreover, the LH is one of the main regions within the hypothalamus that expresses the leptin receptor. Indeed, the activity of these orexincontaining neurons is mitigated by the presence of leptin, as endogenous leptin signaling in the hypothalamus restrains the overconsumption of calorically dense foods [40]. Animal studies and human genetic studies have confirmed that leptin deficiency is associated with a predisposition to obesity [41-43]. Whether by an inability of leptin to reach its neural target, a decrease in leptin isoforms, or decreased expression of leptin receptor [44-45], this "leptin resistance" lends further evidence that the LH is dysregulated, leading to the hypothesis that targeting this region with DBS may disrupt this aberrant circuitry and ameliorate the obese state [46-48]. 


\section{Cureus}

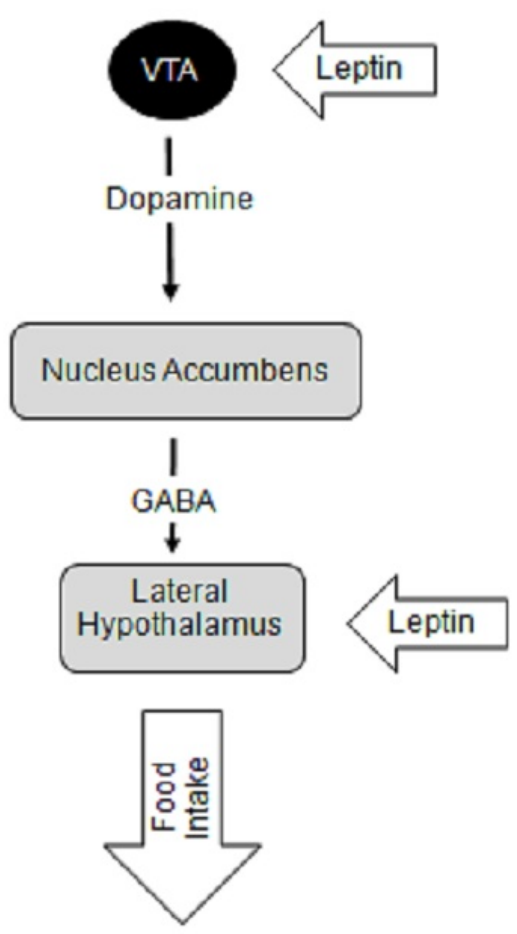

\section{FIGURE 1: Schematic diagram depicting the deep brain stimulation (DBS) targets for obesity and their role in homeostatic pathway of energy balance}

The LH is responsible for providing anabolic feedback onto the autonomic nervous system effectors. The nucleus accumbens (NAC) is the center of the reward pathway in the brain integrating inputs from various high cortical brain areas and the limbic system to reinforce certain beneficial behaviors, such as feeding. Integration of the reward pathways with feeding behavior begins with dopamine release from the ventral tegmental area (VTA) neurons that project onto the nucleus accumbens (NAc). Within the NAc, there are neurons that projection onto the lateral hypothalamus (LH) which contain neurons that stimulate food intake. These nuclei also respond to various hormonal peptides, such as leptin, that are released by the the metabolic systems of the body that link food intake and energy metabolism to the reward pathways within the brain.

In support of this hypothesis, early lesion studies in rats induced leanness, suggesting an important role of the LH in exerting an anabolic effect on the body's metabolic systems [49-50] (Figure 1). Functionally impairing the endogenous activity of the LH with DBS is thought to mimic the effects of these lesions. This stems from experiences with subthalamic nucleus DBS for Parkinson disease, whereby chronic stimulation has the same clinical effects on parkinsonian features as subthalamotomy [51]. Indeed, bilateral DBS studies in rats have demonstrated a 16\% weight loss [52]. Meanwhile, in a recent pilot study of LH DBS in humans, three morbidly obese patients who had previously failed to respond to gastric bypass surgery demonstrated an increase in resting metabolism at their three-year follow-up. Notably, extended follow-up demonstrated a sustained increase in resting metabolic rate with some weight loss in two out of three patients, and without any significant detrimental psychological consequences [53]. A key observation from this early work is the size of the region that DBS must modulate. An increase in metabolism can be achieved with a region as small as $2 \mathrm{~mm}^{2}$ despite the LH's anatomical size measuring approximately 6 × 5 × 3.5 mm laterally, 
anteroposteriorly, and dorsoventrally, respectively [54]. These studies have identified the LH as a promising target for DBS for obesity, however, future clinical studies must verify the optimal location for LH DBS.

\section{Nucleus accumbens and the reward pathway}

Because it houses the hunger and satiety centers of the brain, the hypothalamus has traditionally been the focus of obesity neuromodulation, as detailed above [28-29]. However, many individuals with obesity exhibit many behavioral features of addiction-like behavior, such as binge eating, that is known to be related to dysfunctional reward circuitry in the brain [30$31,55]$. Feelings of craving, reward anticipation, consumption driven reward, and withdrawal are all modulated by the mesocorticolimbic dopaminergic circuitry, which converges on the nucleus accumbens (NAc) [56-57]. Anatomically, the reward circuitry of the brain is composed of dopamine-secreting ventral tegmentum neurons that project to the NAc via the medial forebrain bundle (Figure 1) [58-60]. Access to such a highly palatable, high-caloric diet in rodents has been shown to heighten dopaminergic activity in the brain, which reinforces bingeeating behavior [61-62]. Multiple animal studies of chronic exposure to high-fat diets have demonstrated similar alterations in food consumption mediated by loss of both inhibitory control and withdrawal symptoms[63-64]. Mice conditioned to a high fat diet continuously endure harsh environments to maintain this palatable diet and demonstrate evidence of physiologic withdrawal when weaned from it [66]. A significant increase in markers of stress and decreased dopaminergic signaling within the NAc is seen in these animals after withdrawal from high fat diets [62].

In addition, rodent studies have demonstrated the biochemical, neuroendocrinological, neuroanatomical, and behavioral connections between the lateral hypothalamus and NAc (Figure 1) [65-66]. It is established that glutamate neurons in LH are a major projection site of NAc output neurons, and the NAc is the only striatal region that sends projections to LH [67]. The leptin signaling pathway as well as other gut-derived neuropeptides, such as hormone peptide YY, glucagon-like-peptide 1, and ghrelin, have also been found to project onto this circuitry (Figure 1) [46, 48, 68]. Ventral tegmental dopamine neurons express the leptin receptor and respond to leptin with a reduction in firing rate [68]. Direct administration of leptin to this midbrain structure caused decreased food intake while long-term knockdown of the leptin receptor led to increased food intake, locomotor activity, and sensitivity to highly palatable food. These data support a critical role for the leptin signaling pathway that involves this reward circuitry and the hypothalamic area in regulating feeding behavior. Moreover, this provides functional evidence for direct action of a peripheral metabolic signal on the reward circuit.

In humans, functional imaging studies have played a critical role in establishing the important involvement of the NAc in behaviors associated with obesity. fMRI studies of patients imagining intake of palatable foods found altered activation in the ventral striatum in individuals more at risk for future weight gain [69]. fMRI studies of response to images of high (vs. low) calorie foods or to anticipated receipt of a sweet taste in obese (vs. lean) participants found greater activity in the NAc [70-71]. Decreases in response of the NAc to high (vs. low) calorie food images were found in patients one-month post-roux-en-Y gastric bypass surgery [72]. Two preliminary studies also found a trend for altered dopamine receptor binding potential in the ventral striatum postoperatively in five patients [73-74]. Thus, the NAc must be considered as a potential target for neuromodulation of reward circuitry to control the behavioral patterns of food dependence seen in obese individuals [75].

\section{Nucleus accumbens as a target for DBS}

Classically, the anatomical posterior border of the NAc has been at the level where the anterior 
commissure becomes discontinuous, and it is this posterior region of the nucleus that has achieved the best results when targeted for DBS for psychiatric disorders [76-77]. Proof-ofconcept lesionectomy studies in rodent models have supported the potential efficacy of targeting the NAc with DBS for obesity. For example, in rats given stereotactic 6-OHDA infusions into the NAc, food hoarding behavior was virtually eliminated, and these animals experienced significant weight loss. These effects were readily reversed with levodopa administration [78]. DBS stimulation of the NAc has been performed in multiple animal studies with inconsistent results with regard to effects on feeding behavior, but most studies have not specifically examined the effects of DBS on animal models of obesity or eating disorders [7981]. A recent study by Halpern, et al. demonstrated that DBS of the anteromedial NAc, but not the dorsal striatum, led to a decrease in binge-eating behavior, and this effect was mediated by dopamine signaling involving D2 receptors. This underscores the specificity of involvement of the mesolimbic pathways in food intake related reward pathways. The authors also examined the effects of chronic DBS of the NAc in diet-induced obese mice, and found that NAc stimulation led to decreased caloric intake, sustained weight loss, and improvements in features of Type 2 diabetes [82]. The NAc is a well-validated DBS target, and the safety and efficacy of this anatomic target in humans have already been demonstrated for treating disease processes, such as treatment-refractory depression, OCD, and alcoholism [83-85]. Thus, given the role of the NAc in food-seeking behavior, the NAc is a suitable target for a clinical trial for DBS treatment of refractory obesity.

\section{Ethical considerations}

Data from animal research [52, 86-87] as well as from recent case reports and pilot studies in humans $[84,88]$ have demonstrated the potential of obesity to be therapeutically targeted via DBS. Given the significant data accumulated from animal studies and case reports of obesity treatment with DBS, the specter of a clinical trial of DBS for obesity has raised some ethical considerations. There is significant overlap between obesity and addiction, raising concern for maladaptive behavior as a result of imperfectly executed neural manipulation of the CNS reward circuitry [89]. As with any new treatment for addictive behavior, the possibility for threatened autonomy in the face of behavior-altering treatment is often discussed [90]. Decision-making autonomy prior to treatment is typically preserved in obese patients without other psychiatric or developmental abnormalities as long as informed consent is obtained [91]. Reports of altered behavior ranging from emotional hyperactivity to increased impulsivity to suicidality have been reported [92-93], demonstrating that threatened autonomy can occur in the context of treatment. However, four basic demands for autonomous action include the ability to understand, appreciate, evaluate, and control one's actions in the context of treatment [91]. DBS for morbidly obese patients general satisfy the first three of these requirements, and ultimately goal of treatment would be to attain the fourth in terms of selfcontrol over food consumption.

Given this, we firmly believe that the medical need and scientific justification for treatment of metabolic and eating disorders associated with obesity greatly outweigh the theoretical ethical risks as long as the treatment population is carefully selected. That is, a trial of DBS in obesity should be restricted to treatment refractory patients who have been cautiously evaluated by a multidisciplinary team of obesity specialists, ethicists, and neurosurgeons, and deemed medically and psychologically prepared for postoperative management. Stimulatory parameters of the hypothalamus and reward circuitry should also be carefully studied and modulated on an individual basis so as to not detrimentally alter metabolism or the reward circuitry. Targeting the NAc, in particular, could decrease the reinforcing sensation of consumption, serve as a substitute for the reward of eating, attenuate craving, inhibit a sense of withdrawal, or any combination of these effects. The question of whether attenuation of the reward sensation of food consumption could be achieved without altering a patient's ability to experience other normal pleasure remains to be answered. In light of these considerations, extensive study is 
necessary to define the parameters of stimulation for optimal safety and efficacy. While animals studies will be crucial for defining neural targets, stimulatory parameters, laterality, and mechanism of DBS for obesity, the translation of animal models to human study is not always seamless, and human study will likely have to occur in parallel [94].

\section{Secondary obesity syndromes}

Prader-Willi Syndrome (PWS) is characterized by extreme hyperphagia, obesity, and intellectual disability, and is caused by a genetic defect resulting in absent expression of several imprinted genes in the 15q11-q13 region from the paternal chromosome 15 [95]. PWS patients are often morbidly obese due to their insatiable appetites [96]. One out of three PWS patients are over $200 \%$ ideal body weight, and there have been reports of overconsumption leading to stomach rupture in these patients [97]. The metabolic profile of PWS includes increased adipose to lean mass ratio [98-99], decreased total and resting energy expenditure [100], and elevated fasting ghrelin levels [101]. Despite the most radical medical and surgical interventions, PWS remains difficult to treat. In particular, bariatric surgery has had limited effectiveness and a concerning safety profile, given the increased medical comorbidity in this population [102].

PWS individuals likely have a disruption of basic satiety mechanisms leading them to consume more and for longer periods of time than obese individuals [103-104]. These disruptions manifest as post-meal hyperactivation of the hypothalamus, NAc, amygdala, hippocampus, medial prefrontal cortex (PFC), OFC, and insula, regions involved in both the food satiety and reward circuitry [105-108]. fMRI studies have demonstrated that prior to consumption, individuals with PWS exhibit higher activity in reward/limbic regions (NAc, amygdala) and lower activity in subcortical hunger and satiety regions (hypothalamus, hippocampus), but post-consumption exhibit high activity in subcortical regions and lower activity in inhibitory pre-frontal cortical regions (posterior/lateral OFC, DLPFC) compared to controls. Thus, PWS not only leads to greater activation of reward and hunger centers in anticipation of food, but also disrupts inhibitory circuitry post-prandially [109].

PWS is a common link between food consumption and reward pathways in the brain that when disturbed leads to uncontrolled feeding and morbid obesity (Figure 1). As mentioned previously, LH and NAc are potential targets for PWS that have already been targeted in other disease states. Specifically, the LH has already been targeted via DBS for obesity [53-54] and headache [110] and the NAc for OCD, anxiety, addiction, and depression [76-77]. We propose that these same targets may be potential targets for DBS for PWS.

Kleine-Levin Syndrome (KLS) is a rare episodic hypersomnia disorder that is also characterized by hyperphagia, as well as hypersexuality and cognitive impairment [111-113]. Between episodes, clinical symptoms may resolve entirely. While the pathophysiology of this disorder is largely unknown [113], recent imaging studies have identified aberrations in a variety of deep brain nuclei and cerebral cortical areas.

A 2014 functional MRI (fMRI) study of KLS patients during acute episodes identified hyperactivation of the left thalamus, as well as hypoactivation of the anterior cingulate cortex and medial prefrontal cortex [114]. Another recent study comparing brain perfusion scintigraphy in KLS patients and healthy controls identified hypoperfusion in the hypothalamus, thalamus, caudate nucleus, and frontal and temporal cortical associative areas $[113,115]$. While significant progress remains to be made with regard to the pathophysiology underlying this disease, the identification of abnormalities in several deep brain structures raises the possibility of targeted DBS treatment for KLS.

\section{Conclusions}


In this study, we reviewed the literature implicating the lateral hypothalamus and nucleus accumbens, well-validated DBS targets, in the neural circuitry of obesity. We also presented the current data supporting DBS targeting of these foci to modulate both the metabolic and behavioral pathophysiology involved in treatment-refractory obesity, briefly reviewed ethical considerations for such an intervention, and discussed genetic secondary-obesity syndromes that may benefit from DBS. Though there have been no human studies to date specifically utilizing DBS towards the treatment of obesity, we have provided the scientific foundation and justification for a DBS trial for the treatment of obesity targeting these specific regions of the brain.

\section{Additional Information \\ Disclosures}

Conflicts of interest: In compliance with the ICMJE uniform disclosure form, all authors declare the following: Payment/services info: All authors have declared that no financial support was received from any organization for the submitted work. Financial relationships: All authors have declared that they have no financial relationships at present or within the previous three years with any organizations that might have an interest in the submitted work. Other relationships: All authors have declared that there are no other relationships or activities that could appear to have influenced the submitted work.

\section{References}

1. Field AE, Coakley EH, Must A, Spadano JL, Laird N, Dietz WH, Rimm E, Colditz GA: Impact of overweight on the risk of developing common chronic diseases during a 10-year period. Arch Intern Med. 2001, 161:1581-1586. 10.1001/archinte.161.13.1581

2. Fontaine KR, Redden DT, Wang C, Westfall AO, Allison DB: Years of life lost due to obesity . JAMA. 2003, 289:187-193. 10.1001/jama.289.2.187

3. Must A, Spadano J, Coakley EH, Field AE, Colditz G, Dietz WH: The disease burden associated with overweight and obesity. JAMA. 1999, 282:1523-1529. 10.1001/jama.282.16.1523

4. Roe DA, Eickwort KR: Relationships between obesity and associated health factors with unemployment among low income women. J Am Med Womens Assoc. 1976, 31:193-4, 198-9, 203-4.

5. Ogden CL, Carroll MD, Kit BK, Flegal KM: Prevalence of childhood and adult obesity in the United States, 2011-2012. JAMA. 2014, 311:806-814. 10.1001/jama.2014.732

6. Flegal KM, Carroll MD, Kit BK, Ogden CL: Prevalence of obesity and trends in the distribution of body mass index among US adults, 1999-2010. JAMA. 2012, 307:491-497. 10.1001/jama.2012.39

7. Danaei G, Ding EL, Mozaffarian D, Taylor B, Rehm J, Murray CJ, Ezzati M: The preventable causes of death in the United States: comparative risk assessment of dietary, lifestyle, and metabolic risk factors. PLoS Med. 2009, 6:e1000058. 10.1371/journal.pmed.1000058

8. Allison DB, Zannolli R, Narayan KM: The direct health care costs of obesity in the United States. Am J Public Health. 1999, 89:1194-99. 10.2105/AJPH.89.8.1194

9. Jeffery RW, Kelly KM, Rothman AJ, Sherwood NE, Boutelle KN: The weight loss experience: a descriptive analysis. Ann Behav Med. 2004, 27:100-106. 10.1207/s15324796abm2702_4

10. Li Z, Maglione M, Tu W, Mojica W, Arterburn D, Shugarman LR, Hilton L, Suttorp M, Solomon V, Shekelle PG, Morton SC: Meta-analysis: pharmacologic treatment of obesity. Ann Intern Med. 2005, 142:532-546. 10.7326/0003-4819-142-7-200504050-00012

11. Sturm R: Increases in morbid obesity in the USA: 2000-2005 . Public Health. 2007, 121:492-6. 10.1016/j.puhe.2007.01.006

12. Magro DO, Geloneze B, Delfini R, Pareja BC, Callejas F, Pareja JC: Long-term weight regain after gastric bypass: a 5-year prospective study. Obes Surg. 2008, 18:648-651. 10.1007/s11695007-9265-1

13. Orlando FA, Goncalves CG, George ZM, Halverson JD, Cunningham PR, Meguid MM: Neurohormonal pathways regulating food intake and changes after Roux-en-Y gastric bypass . Surg Obes Relat Dis. 2005, 1:486-495. 10.1016/j.soard.2005.05.009 
14. Christou NV, Look D, Maclean LD: Weight gain after short- and long-limb gastric bypass in patients followed for longer than 10 years. Ann Surg. 2006, 244:734-740.

10.1097/01.sla.0000217592.04061.d5

15. Gracia-Solanas JA, Elia M, Aguilella V, Ramirez JM, Martinez J, Bielsa MA, Martinez M: Metabolic syndrome after bariatric surgery. Results depending on the technique performed . Obes Surg. 2011, 21:179-185. 10.1007/s11695-010-0309-6

16. Halpern C, Hurtig H, Jaggi J, Grossman M, Won M, Baltuch G: Deep brain stimulation in neurologic disorders. Parkinsonism Relat Disord. 2007, 13:1-16.

10.1016/j.parkreldis.2006.03.001

17. Tagliati M, Krack P, Volkmann J, Aziz T, Krauss JK, Kupsch A, Vidailhet AM: Long-term management of DBS in dystonia: response to stimulation, adverse events, battery changes, and special considerations. Mov Disord. 2011, 26:54-62. 10.1002/mds.23535

18. Toft M, Lilleeng B, Ramm-Pettersen J, Skogseid IM, Gundersen V, Gerdts R, Pedersen L, Skjelland M, Roste GK, Dietrichs E: Long-term efficacy and mortality in Parkinson's disease patients treated with subthalamic stimulation. Mov Disord. 2011, 26:1931-1934. 10.1002/mds. 23817

19. Gradinaru V, Mogri M, Thompson KR, Henderson JM, Deisseroth K: Optical deconstruction of parkinsonian neural circuitry. Science. 2009, 324:354-359. 10.1126/science.1167093

20. Lee KH, Kristic K, van Hoff R, Hitti FL, Blaha C, Harris B, Roberts DW, Leiter JC: Highfrequency stimulation of the subthalamic nucleus increases glutamate in the subthalamic nucleus of rats as demonstrated by in vivo enzyme-linked glutamate sensor. Brain Res. 2007, 1162:121-129.

21. Andy OJ, Jurko MF, Sias FR, Jr: Subthalamotomy in Treatment of Parkinsonian Tremor . J Neurosurg. 1963, 20:860-870.

22. Bingley T, Persson A: EEG studies on patients with chronic obsessive-compulsive neurosis before and after psychosurgery (stereotaxic bilateral anterior capsulotomy). Electroencephalogr Clin Neurophysiol. 1978, 44:691-696.

23. Csigo K, Harsanyi A, Demeter G, Rajkai C, Nemeth A, Racsmany M: Long-term follow-up of patients with obsessive-compulsive disorder treated by anterior capsulotomy: a neuropsychological study. J Affect Disord. 2010, 126:198-205. 10.1016/j.jad.2010.02.127

24. Krayenbuhl H, Wyss OA, Yasargil MG: Bilateral thalamotomy and pallidotomy as treatment for bilateral Parkinsonism. J Neurosurg. 1961, 18:429-444. 10.3171/jns.1961.18.4.0429

25. Mayberg HS, Lozano AM, Voon V, McNeely HE, Seminowicz D, Hamani C, Schwalb JM, Kennedy SH: Deep brain stimulation for treatment-resistant depression . Neuron. 2005, 45:651-660.

26. Schoenen J, Di Clemente L, Vandenheede M, Fumal A, De Pasqua V, Mouchamps M, Remacle JM, de Noordhout AM: Hypothalamic stimulation in chronic cluster headache: a pilot study of efficacy and mode of action. Brain. 2005, 128:940-947. 10.1093/brain/awh411

27. Chabardès S, Polosan M, Krack P, Bastin J, Krainik A, David O, Bougerol T, Benabid AL: Deep brain stimulation for obsessive-compulsive disorder: subthalamic nucleus target. World Neurosurg. 2013, 80:S31. 10.1016/j.wneu.2012.03.010

28. van de Sande-Lee S, Pereira FR, Cintra DE, Fernandes PT, Cardoso AR, Garlipp CR, Chaim EA, Pareja JC, Geloneze B, Li LM, Cendes F, Velloso LA: Partial reversibility of hypothalamic dysfunction and changes in brain activity after body mass reduction in obese subjects. Diabetes. 2011, 60:1699-1704. 10.2337/db10-1614

29. Wyrwicka W, Dobrzecka C: Relationship between feeding and satiation centers of the hypothalamus. Science. 1960, 132:805-806. 10.1126/science.132.3430.805

30. Gearhardt AN, Yokum S, Orr PT, Stice E, Corbin WR, Brownell KD: Neural correlates of food addiction. Arch Gen Psychiatry. 2011, 68:808-816. 10.1001/archgenpsychiatry.2011.32

31. Johnson PM, Kenny PJ: Dopamine D2 receptors in addiction-like reward dysfunction and compulsive eating in obese rats. Nat Neurosci. 2010, 13:635-641. 10.1038/nn.2519

32. Knapp CM, Tozier L, Pak A, Ciraulo DA, Kornetsky C: Deep brain stimulation of the nucleus accumbens reduces ethanol consumption in rats. Pharmacol Biochem Behav. 2009, 92:474479. 10.1016/j.pbb.2009.01.017

33. Griffond B, Risold PY: MCH and feeding behavior-interaction with peptidic network. Peptides. 2009, 30:2045-2051. 10.1016/j.peptides.2009.07.008

34. Ludwig DS, Tritos NA, Mastaitis JW, Kulkarni R, Kokkotou E, Elmquist J, Lowell B, Flier JS, Maratos-Flier E: Melanin-concentrating hormone overexpression in transgenic mice leads to 
obesity and insulin resistance. J Clin Invest. 2001, 107:379-386. 10.1172/JCI10660

35. de Lecea L, Kilduff TS, Peyron C, Gao X, Foye PE, Danielson PE, Fukuhara C, Battenberg EL, Gautvik VT, Bartlett FS, 2nd, Frankel WN, van den Pol AN, Bloom FE, Gautvik KM, Sutcliffe JG: The hypocretins: hypothalamus-specific peptides with neuroexcitatory activity . Proc Natl Acad Sci U S A. 1998, 95:322-327.

36. Peyron C, Tighe DK, van den Pol AN, de Lecea L, Heller HC, Sutcliffe JG, Kilduff TS: Neurons containing hypocretin (orexin) project to multiple neuronal systems. J Neurosci. 1998, 18:9996-10015.

37. Sakurai T, Amemiya A, Ishii M, Matsuzaki I, Chemelli RM, Tanaka H, Williams SC, Richarson JA, Kozlowski GP, Wilson S, Arch JR, Buckingham RE, Haynes AC, Carr SA, Annan RS, McNulty DE, Liu WS, Terrett JA, Elshourbagy NA, Bergsma DJ, Yanagisawa M: Orexins and orexin receptors: a family of hypothalamic neuropeptides and $\mathrm{G}$ protein-coupled receptors that regulate feeding behavior. Cell. 1998, 92:1 page following 696.

38. Bewick GA, Gardiner JV, Dhillo WS, Kent AS, White NE, Webster Z, Ghatei MA, Bloom SR: Post-embryonic ablation of AgRP neurons in mice leads to a lean, hypophagic phenotype . FASEB J. 2005, 19:1680-1682. 10.1096/fj.04-3434fje

39. Elmquist JK, Elias CF, Saper CB: From lesions to leptin: hypothalamic control of food intake and body weight. Neuron. 1999, 22:221-232. 10.1016/S0896-6273(00)81084-3

40. Davis JF, Choi DL, Schurdak JD, Fitzgerald MF, Clegg DJ, Lipton JW, Figlewicz DP, Benoit SC: Leptin regulates energy balance and motivation through action at distinct neural circuits . Biol Psychiatry. 2011, 69:668-674. 10.1016/j.biopsych.2010.08.028

41. Munzberg H, Bjornholm M, Bates SH, Myers MG, Jr: Leptin receptor action and mechanisms of leptin resistance. Cell Mol Life Sci. 2005, 62:642-652. 10.1007/s00018-004-4432-1

42. Zhang Y, Proenca R, Maffei M, Barone M, Leopold L, Friedman JM: Positional cloning of the mouse obese gene and its human homologue. Nature. 1994, 372:425-432.

43. Wabitsch M, Funcke JB, Lennerz B, Kuhnle-Krahl U, Lahr G, Debatin KM, Vatter P, Gierschik P, Moepps B, Fischer-Posovszky P: Biologically inactive leptin and early-onset extreme obesity. NEJM. 2015, 372:48-54. 10.1056/NEJMoa1406653

44. Banks WA, Coon AB, Robinson SM, Moinuddin A, Shultz JM, Nakaoke R, Morley JE: Triglycerides induce leptin resistance at the blood-brain barrier . Diabetes. 2004, 53:12531260. 10.2337/diabetes.53.5.1253

45. Mori H, Hanada R, Hanada T, Aki D, Mashima R, Nishinakamura H, Torisu T, Chien KR, Yasukawa H, Yoshimura A: Socs3 deficiency in the brain elevates leptin sensitivity and confers resistance to diet-induced obesity. Nature Med. 2004, 10:739-743. 10.1038/nm1071

46. Schloegl H, Percik R, Horstmann A, Villringer A, Stumvoll M: Peptide hormones regulating appetite--focus on neuroimaging studies in humans. Diabetes Metab Res Rev. 2011, $27: 104-$ 112. 10.1002/dmrr.1154

47. Shin JI, Park SJ, Kim JH: A possible role of leptin-associated increase in soluble interleukin-2 receptor diminishing a clinical response to infliximab in rheumatoid arthritis: Comment on the article by Klaasen et al. Arthritis Rheum. 2011, 63:2833-2834. 10.1002/art.30462

48. Skibicka KP, Hansson C, Alvarez-Crespo M, Friberg PA, Dickson SL: Ghrelin directly targets the ventral tegmental area to increase food motivation. Neuroscience. 2011, 180:129-137. 10.1016/j.neuroscience.2011.02.016

49. Harrell LE, Decastro JM, Balagura S: A critical evaluation of body weight loss following lateral hypothalamic lesions. Physiol Behav. 1975, 15:133-136.

50. Keesey RE, Powley TL: Self-stimulation and body weight in rats with lateral hypothalamic lesions. Am J Physiol. 1973, 224:970-978.

51. Krack P, Batir A, Van Blercom N, Chabardes S, Fraix V, Ardouin C, Koudsie A, Limousin PD, Benazzouz A, LeBas JF, Benabid AL, Pollak P: Five-year follow-up of bilateral stimulation of the subthalamic nucleus in advanced Parkinson's disease. NEJM. 2003, 349:1925-1934. 10.1056/NEJMoa035275

52. Sani S, Jobe K, Smith A, Kordower JH, Bakay RA: Deep brain stimulation for treatment of obesity in rats. J Neurosurg. 2007, 107:809-813.

53. Whiting DM, Tomycz ND, Bailes J, de Jonge L, Lecoultre V, Wilent B, Alcindor D, Prostko ER, Cheng BC, Angle C, Cantella D, Whiting BB, Mizes JS, Finnis KW, Ravussin E, Oh MY: Lateral hypothalamic area deep brain stimulation for refractory obesity: a pilot study with preliminary data on safety, body weight, and energy metabolism. J Neurosurg. 2013, 119:5663. 10.3171/2013.2.JNS12903 
54. Schaltenbrand GW, Wahren W: Atlas for Stereotaxy of the Human Brain. Georg Thieme Publishers, Stuttgart; 1977.

55. Kenny PJ: Reward mechanisms in obesity: new insights and future directions . Neuron. 2011, 69:664-679. 10.1016/j.neuron.2011.02.016

56. Volkow ND, Wang GJ, Telang F, Fowler JS, Logan J, Childress AR, Jayne M, Ma Y, Wong C: Cocaine cues and dopamine in dorsal striatum: mechanism of craving in cocaine addiction . J Neurosci. 2006, 26:6583-6588. 10.1523/JNEUROSCI.1544-06.2006

57. Whitfield TW Jr, Shi X, Sun WL, McGinty JF: The suppressive effect of an intra-prefrontal cortical infusion of BDNF on cocaine-seeking is Trk receptor and extracellular signalregulated protein kinase mitogen-activated protein kinase dependent. J Neurosci. 2011, 31:834-842. 10.1523/JNEUROSCI.4986-10.2011

58. Di Chiara G: Nucleus accumbens shell and core dopamine: differential role in behavior and addiction. Behav Brain Res. 2002, 137:75-114. 10.1016/S0166-4328(02)00286-3

59. Nestler EJ, Malenka RC: The addicted brain. Sci Am. 2004, 290:78-85. 10.1038/scientificamerican0304-78

60. Volkow ND, Li TK: Drug addiction: the neurobiology of behaviour gone awry . Nat Rev Neurosci. 2004, 5:963-970. 10.1038/nrn1539

61. Blendy JA, Maldonado R: Genetic analysis of drug addiction: the role of cAMP response element binding protein. J Mol Med (Berl). 1998, 76:104-110. 10.1007/s001090050197

62. Teegarden SL, Bale TL: Decreases in dietary preference produce increased emotionality and risk for dietary relapse. Biol Psychiatry. 2007, 61:1021-1029. 10.1016/j.biopsych.2006.09.032

63. Kober H, Mende-Siedlecki P, Kross EF, Weber J, Mischel W, Hart CL, Ochsner KN: Prefrontalstriatal pathway underlies cognitive regulation of craving. Proc Natl Acad Sci U S A. 2010, 107:14811-14816. 10.1073/pnas.1007779107

64. Volkow ND, Wang GJ, Telang F, Fowler JS, Thanos PK, Logan J, Alexoff D, Ding YS, Wong C, Ma Y, Pradhan K: Low dopamine striatal D2 receptors are associated with prefrontal metabolism in obese subjects: possible contributing factors. Neuroimage. 2008, 42:15371543. 10.1016/j.neuroimage.2008.06.002

65. Huang XF, Han M, South T, Storlien L: Altered levels of POMC, AgRP and MC4-R mRNA expression in the hypothalamus and other parts of the limbic system of mice prone or resistant to chronic high-energy diet-induced obesity. Brain Res. 2003, 992:9-19. 10.1016/j.brainres.2003.08.019

66. Maldonado-Irizarry CS, Swanson CJ, Kelley AE: Glutamate receptors in the nucleus accumbens shell control feeding behavior via the lateral hypothalamus. J Neurosci. 1995, 15:6779-6788.

67. Mogenson GJ, Swanson LW, Wu M: Neural projections from nucleus accumbens to globus pallidus, substantia innominata, and lateral preoptic-lateral hypothalamic area: an anatomical and electrophysiological investigation in the rat. J Neurosci. 1983, 3:189-202.

68. Hommel JD, Trinko R, Sears RM, Georgescu D, Liu ZW, Gao XB, Thurmon JJ, Marinelli M, DiLeone RJ: Leptin receptor signaling in midbrain dopamine neurons regulates feeding . Neuron. 2006, 51:801-810. 10.1016/j.neuron.2006.08.023

69. Stice E, Yokum S, Bohon C, Marti N, Smolen A: Reward circuitry responsivity to food predicts future increases in body mass: moderating effects of DRD2 and DRD4. Neuroimage. 2010, 50:1618-1625. 10.1016/j.neuroimage.2010.01.081

70. O'Doherty JP, Deichmann R, Critchley HD, Dolan RJ: Neural responses during anticipation of a primary taste reward. Neuron. 2002, 33:815-826. 10.1016/S0896-6273(02)00603-7

71. Stoeckel LE, Weller RE, Cook EW, 3rd, Twieg DB, Knowlton RC, Cox JE: Widespread rewardsystem activation in obese women in response to pictures of high-calorie foods. Neuroimage. 2008, 41:636-647. 10.1016/j.neuroimage.2008.02.031

72. Ochner CN, Kwok Y, Conceicao E, Pantazatos SP, Puma LM, Carnell S, Teixeira J, Hirsch J, Geliebter A: Selective reduction in neural responses to high calorie foods following gastric bypass surgery. Ann Surg. 2011, 253:502-507. 10.1097/SLA.0b013e318203a289

73. Dunn JP, Cowan RL, Volkow ND, Feurer ID, Li R, Williams DB, Kessler RM, Abumrad NN: Decreased dopamine type 2 receptor availability after bariatric surgery: preliminary findings . Brain Res. 2010, 1350:123-130. 10.1016/j.brainres.2010.03.064

74. Steele KE, Prokopowicz GP, Schweitzer MA, Magunsuon TH, Lidor AO, Kuwabawa H, Kumar A, Brasic J, Wong DF: Alterations of central dopamine receptors before and after gastric bypass surgery. Obes Surg. 2010, 20:369-374. 10.1007/s11695-009-0015-4 
75. Mahler SV, de Wit H: Cue-reactors: individual differences in cue-induced craving after food or smoking abstinence. PLoS One. 2010, 5:e15475. 10.1371/journal.pone.0015475

76. Sturm V, Lenartz D, Koulousakis A, Treuer H, Herholz K, Klein JC, Klosterkotter J: The nucleus accumbens: a target for deep brain stimulation in obsessive-compulsive- and anxietydisorders. J Chem Neuroanat. 2003, 26:293-299. 10.1016/j.jchemneu.2003.09.003

77. Lucas-Neto L, Mourato B, Neto D, Oliveira E, Martins H, Correia F, Goncalves-Ferreira A: The Nucleus Accumbens beyond the Anterior Commissure: Implications for Psychosurgery.

Stereotact Funct Neurosurg. 2014, 92:291-299. 10.1159/000365115

78. Kelley AE, Stinus L: Disappearance of hoarding behavior after 6-hydroxydopamine lesions of the mesolimbic dopamine neurons and its reinstatement with L-dopa. Behav Neurosci. 1985, 99:531-545. 10.1037/0735-7044.99.3.531

79. Goldstein JM, Siegel J: Suppression of attack behavior in cats by stimulation of ventral tegmental area and nucleus accumbens. Brain Res. 1980, 183:181-192. 10.1016/00068993(80)90128-6

80. McCracken CB, Grace AA: High-frequency deep brain stimulation of the nucleus accumbens region suppresses neuronal activity and selectively modulates afferent drive in rat orbitofrontal cortex in vivo. J Neurosci. 2007, 27:12601-12610. 10.1523/JNEUROSCI.375007.2007

81. Murer MG, Pazo JH: Behavioral responses induced by electrical stimulation of the caudate nucleus in freely moving cats. Behav Brain Res. 1993, 57:9-19. 10.1016/0166-4328(93)90056$\mathrm{V}$

82. Halpern CH, Tekriwal A, Santollo J, Keating JG, Wolf JA, Daniels D, Bale TL: Amelioration of binge eating by nucleus accumbens shell deep brain stimulation in mice involves D2 receptor modulation. J Neurosci. 2013, 33:7122-7129. 10.1523/JNEUROSCI.3237-12.2013

83. Goodman WK, Foote KD, Greenberg BD, Ricciuti N, Bauer R, Ward H, Shapira NA, Wu SS, Hill CL, Rasmussen SA, Okun MS: Deep brain stimulation for intractable obsessive compulsive disorder: pilot study using a blinded, staggered-onset design. Biol Psychiatry. 2010, 67:535542. 10.1016/j.biopsych.2009.11.028

84. Muller UJ, Sturm V, Voges J, Heinze HJ, Galazky I, Heldmann M, Scheich H, Bogerts B: Successful treatment of chronic resistant alcoholism by deep brain stimulation of nucleus accumbens: first experience with three cases. Pharmacopsychiatry. 2009, 42:288-291. 10.1055/s-0029-1233489

85. Schlaepfer TE, Cohen MX, Frick C, Kosel M, Brodesser D, Axmacher N, Joe AY, Kreft M, Lenartz D, Sturm V: Deep brain stimulation to reward circuitry alleviates anhedonia in refractory major depression. Neuropsychopharmacology. 2008, 33:368-377.

10.1038/sj.npp.1301408

86. Brown FD, Fessler RG, Rachlin JR, Mullan S: Changes in food intake with electrical stimulation of the ventromedial hypothalamus in dogs. J Neurosurg. 1984, 60:1253-1257. 10.3171/jns.1984.60.6.1253

87. Ruffin M, Nicolaidis S: Electrical stimulation of the ventromedial hypothalamus enhances both fat utilization and metabolic rate that precede and parallel the inhibition of feeding behavior. Brain Res. 1999, 846:23-29. 10.1016/S0006-8993(99)01922-8

88. Mantione M, van de Brink W, Schuurman PR, Denys D: Smoking cessation and weight loss after chronic deep brain stimulation of the nucleus accumbens: therapeutic and research implications: case report. Neurosurg. 2010, 66:218-218.

10.1227/01.NEU.0000360570.40339.64

89. Carter A, Hall W: Proposals to trial deep brain stimulation to treat addiction are premature. Addiction. 2011, 106:235-237. 10.1111/j.1360-0443.2010.03245.x

90. Caplan A: Denying autonomy in order to create it: the paradox of forcing treatment upon addicts. Addiction. 2008, 103:1919-1921. 10.1111/j.1360-0443.2008.02369.x.

91. Unterrainer M, Oduncu FS: The ethics of deep brain stimulation (DBS). Medicine, health care, and philosophy. 2015 Jan 18, [Epub ahead of print]:

92. Voon V, Krack P, Lang AE, Lozano AM, Dujardin K, Schupbach M, D'Ambrosia J, Thobois S, Tamma F, Herzog J, Speelman JD, Samanta J, Kubu C, Rossignol H, Poon YY, Saint-Cyr JA, Ardouin C, Moro E: A multicentre study on suicide outcomes following subthalamic stimulation for Parkinson's disease. Brain. 2008, 131:2720-2728. 10.1093/brain/awn214 27202728

93. Houeto JL, Mesnage V, Mallet L, Pillon B, Gargiulo M, du Moncel ST, Bonnet AM, Pidoux B, 
Dormont D, Cornu P, Agid Y: Behavioural disorders, Parkinson's disease and subthalamic stimulation. J Neurol Neurosurg Psychiatry. 2002, 72:701-707. 10.1136/jnnp.72.6.701

94. Frazer A, Morilak DA: What should animal models of depression model? . Neurosci Biobehav Rev. 2005, 29:515-523. 10.1016/j.neubiorev.2005.03.006

95. Bittel DC, Butler MG: Prader-Willi syndrome: clinical genetics, cytogenetics and molecular biology. Expert Rev Mol Med. 2005, 7:1-20. 10.1017/S1462399405009531

96. Butler MG: Prader-Willi syndrome: current understanding of cause and diagnosis. Am J Med Genet. 1990, 35:319-332. 10.1002/ajmg.1320350306

97. Stevenson DA, Heinemann J, Angulo M, Butler MG, Loker J, Rupe N, Kendell P, Cassidy SB, Scheimann A: Gastric rupture and necrosis in Prader-Willi syndrome. J Pediatr Gastroenterol Nutr. 2007, 45:272-274. 10.1097/MPG.0b013e31805b82b5

98. Kennedy L, Bittel DC, Kibiryeva N, Kalra SP, Torto R, Butler MG: Circulating adiponectin levels, body composition and obesity-related variables in Prader-Willi syndrome: comparison with obese subjects. Int J Obes (Lond). 2006, 30:382-387. 10.1038/sj.ijo.0803115

99. Theodoro MF, Talebizadeh Z, Butler MG: Body composition and fatness patterns in PraderWilli syndrome: comparison with simple obesity. Obesity. 2006, 14:1685-1690. 10.1038/oby.2006.193

100. Butler MG, Theodoro MF, Bittel DC, Donnelly JE: Energy expenditure and physical activity in Prader-Willi syndrome: comparison with obese subjects. American journal of medical genetics Part. Am J Med Genet A. 2007, 143:449-459. 10.1002/ajmg.a.31507

101. Haqq AM, Farooqi IS, O'Rahilly S, Stadler DD, Rosenfeld RG, Pratt KL, LaFranchi SH, Purnell JQ: Serum ghrelin levels are inversely correlated with body mass index, age, and insulin concentrations in normal children and are markedly increased in Prader-Willi syndrome. J Clin Endocrinol Metab. 2003, 88:174-178. 10.1210/jc.2002-021052

102. Scheimann AO, Butler MG, Gourash L, Cuffari C, Klish W: Critical analysis of bariatric procedures in Prader-Willi syndrome. J Pediatr Gastroenterol Nutr. 2008, 46:80-83. 10.1097/01.mpg.0000304458.30294.31

103. Lindgren AC, Barkeling B, Hagg A, Ritzen EM, Marcus C, Rossner S: Eating behavior in PraderWilli syndrome, normal weight, and obese control groups. J Pediatr. 2000, 137:50-55.

10.1067/mpd.2000.106563

104. Zipf WB, Berntson GG: Characteristics of abnormal food-intake patterns in children with Prader-Willi syndrome and study of effects of naloxone. Am J Clin Nutr. 1987, 46:277-281.

105. Shapira NA, Lessig MC, He AG, James GA, Driscoll DJ, Liu Y: Satiety dysfunction in PraderWilli syndrome demonstrated by fMRI. J Neurol Neurosurg Psychiatry. 2005, 76:260-262. 10.1136/jnnp.2004.039024

106. Holsen LM, Zarcone JR, Brooks WM, Butler MG, Thompson TI, Ahluwalia JS, Nollen NL, Savage CR: Neural mechanisms underlying hyperphagia in Prader-Willi syndrome. Obesity. 2006, 14:1028-1037.10.1038/oby.2006.118

107. Miller JL, James GA, Goldstone AP, Couch JA, He G, Driscoll DJ, Liu Y: Enhanced activation of reward mediating prefrontal regions in response to food stimuli in Prader-Willi syndrome. J Neurol Neurosurg Psychiatry. 2007, 78:615-619. 10.1136/jnnp.2006.099044

108. Hinton EC, Holland AJ, Gellatly MS, Soni S, Patterson M, Ghatei MA, Owen AM: Neural representations of hunger and satiety in Prader-Willi syndrome. Int J Obes (Lond). 2006, 30:313-321. 10.1038/sj.ijo.0803128

109. Holsen LM, Savage CR, Martin LE, Bruce AS, Lepping RJ, Ko E, Brooks WM, Butler MG, Zarcone JR, Goldstein JM: Importance of reward and prefrontal circuitry in hunger and satiety: Prader-Willi syndrome vs simple obesity. Int J Obes (Lond). 2012, 36:638-647. 10.1038/ijo.2011.204

110. Jenkins B, Tepper SJ: Neurostimulation for primary headache disorders: Part 2, review of central neurostimulators for primary headache, overall therapeutic efficacy, safety, cost, patient selection, and future research in headache neuromodulation. Headache. 2011, 51:1408-1418. 10.1111/j.1526-4610.2011.01967.x

111. Billiard M, Jaussent I, Dauvilliers Y, Besset A: Recurrent hypersomnia: a review of 339 cases . Sleep Med Rev. 2011, 15:247-257. 10.1016/j.smrv.2010.08.001

112. Drakatos P, Leschziner GD: Update on hypersomnias of central origin. Curr Opin Pulm Med. 2014, 20:572-580. 10.1097/MCP.0000000000000098

113. Miglis MG, Guilleminault C: Kleine-Levin syndrome: a review . Nat Sci Sleep. 2014, 6:19-26. 10.2147/NSS.S44750 


\section{Cureus}

114. Engstrom M, Hallbook T, Szakacs A, Karlsson T, Landtblom AM: Functional magnetic resonance imaging in narcolepsy and the kleine-levin syndrome. Front Neurol. 2014, 5:105 10.3389/fneur.2014.00105

115. Landtblom AM, Dige N, Schwerdt K, Safstrom P, Granerus G: A case of Kleine-Levin syndrome examined with SPECT and neuropsychological testing. Acta Neurol Scand. 2002, 105:318-321. 10.1034/j.1600-0404.2002.1c162.x 